This item was submitted to Loughborough's Research Repository by the author.

Items in Figshare are protected by copyright, with all rights reserved, unless otherwise indicated.

\title{
Beyond cognitivism
}

PLEASE CITE THE PUBLISHED VERSION

http://dx.doi.org/10.1080/08351813.1999.9683615

PUBLISHER

(c) Lawrence Erlbaum Associates, Inc.

VERSION

AM (Accepted Manuscript)

LICENCE

CC BY-NC-ND 4.0

REPOSITORY RECORD

Potter, Jonathan. 2019. "Beyond Cognitivism". figshare. https://hdl.handle.net/2134/9435. 
This item was submitted to Loughborough's Institutional Repository (https://dspace.lboro.ac.uk/) by the author and is made available under the following Creative Commons Licence conditions.

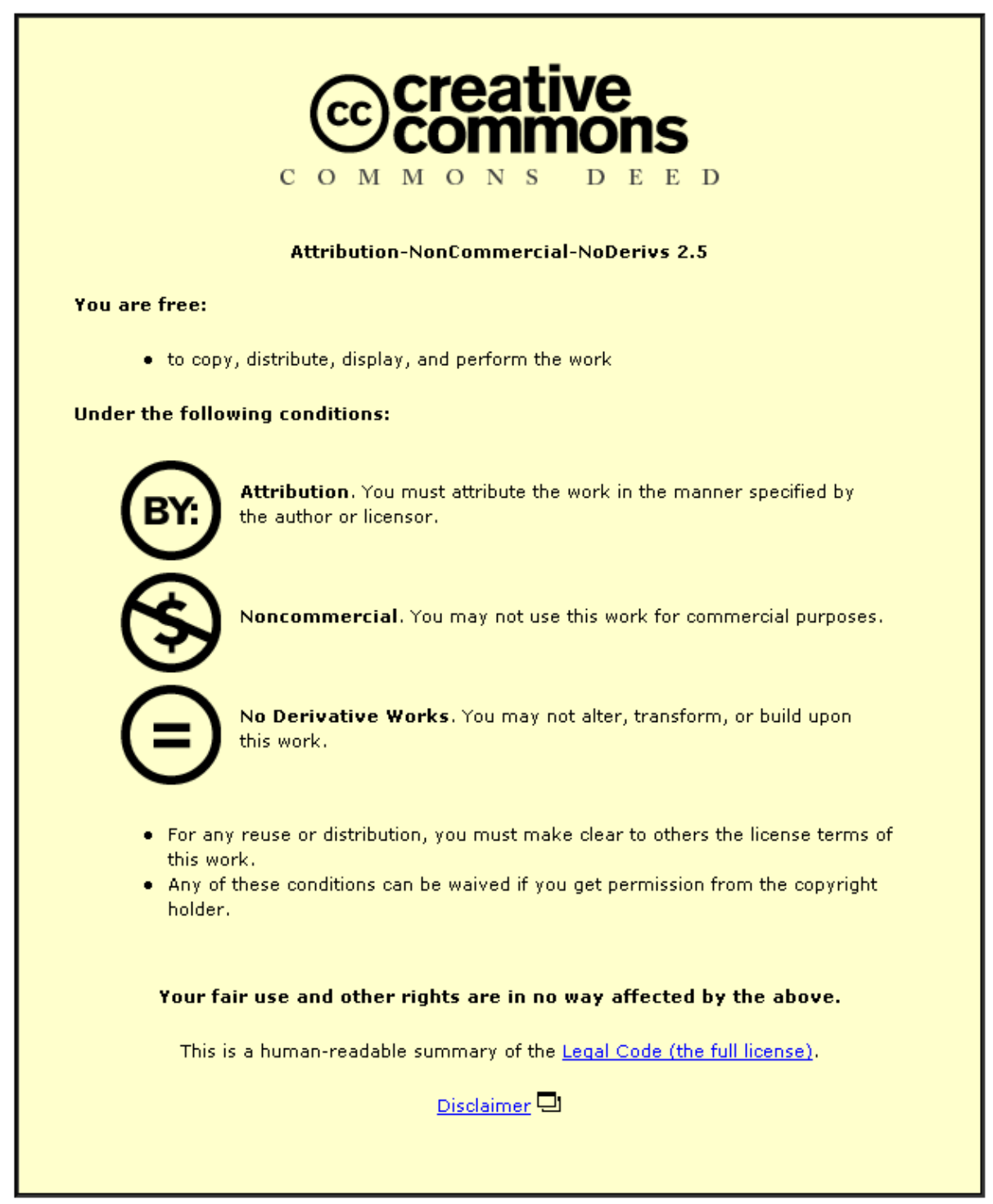

For the full text of this licence, please go to: http://creativecommons.org/licenses/by-nc-nd/2.5/ 


\section{BEYOND COGNITIVISM}

\section{Jonathan Potter}

Discourse and Rhetoric Group

Department of Social Sciences

Loughborough University

Loughborough

Leicestershire, LE11 3TU
Email: J.A.Potter@lboro.ac.uk

Tel: 01509223384

Fax: 01509223944

I would like to thank Charles Antaki, Derek Edwards, Alexa Hepburn and Celia Kitzinger for comments on a previous draft of this paper.

For: Language and Social Interaction Study at the Century's Turn, special issue of Research on Language and Social Interaction

1 March, 2012 
What is the appropriate relationship between the fields of language and social interaction (LSI) research and cognitive psychology? I wish to speculate about one possible future where LSI hijacks much of the action which would have been considered the province of cognitive psychology, respecifying and reorienting it as it does so. In this future LSI becomes a foundational discipline in the social sciences rather than existing merely to service one of a wide array of different topic areas. It is a future of ambition and creative argument. LSI might need a name change, though.

\section{TWO MODELS OF LSI}

Let me start by distinguishing between two extreme models of LSI and its relationship to other areas of social science. On the one hand, there is a model in which social life is an array of intersecting modules and levels and the different social sciences sub-fields study these different modules and levels to improve understanding. They provide complementary analyses of topics such as semantics, registers, cognitive representations and ideology which can be articulated together to contribute to a larger picture. Here the field is defined by topic rather than by method or theory. This model of LSI is presented in both the introduction and the organization of Teun van Dijk's (1997) (excellent) volumes on discourse studies. I will call this the Complementary Model of LSI.

On the other hand, there is a model of the relationship between LSI and other areas of social science which, instead of offering complementary analyses, proposes instead a wholesale respecification of topics, methods and questions. Ethnomethodological conversation analysis is one perspective in LSI which is characterised by the respecification of a wide range of social science notions; post-structuralism offers another perspective calling for a root and branch disciplinary overhaul. For example, in conversation analysis, the 
attempt is not to relate institutions, as prior existing and clearly identifiable phenomena, with the more ephemeral waxing and waning of talk; rather institutional realities are treated as constituted in talk in a variety of ways as participants construct and orient to institutional goals and identities (Drew \& Sorjonen, 1997; Heritage 1997). I will call this the Respecification Model of LSI.

Quite apart from any theoretical and analytic grounds for preferring one model over another, the Respecification Model has the virtue of promoting potentially productive debate across the social sciences. So far, this model has had its most powerful effects in sociology, where ethnomethodological conversation analysis has developed a radically different approach to issues of social structure. However, there has, as yet, been relatively little argument at the intersection of LSI and cognitive psychology.

\section{Discourse AND Cognition}

The boundary of LSI and cognitive psychology has been colonised by the thriving research tradition of discourse processes ('discourse' signalled linguistic issues that go beyond the sentence; 'processes' suggested that these issues might be dealt with by cognitive processes of one kind or another). The Complementary Model is at work here to sustain a seamless transition between cognitive psychology and LSI research with the boundary area covered by ROLSI's sister journal Discourse Processes, by the sorts of social cognition work (in speech accommodation and so on) published in the Journal of Language and Social Psychology, and by the various books in the Advances in Discourse Processes series.

In the Respecification Model things are more complicated. There has been a tradition of Wittgenstein influenced critique of cognitivism in ethnomethodology for some time (Button, et al., 1995; Coulter, 1990). Although much of this was a conceptual reworking of 
Wittgensteinian notions in the light of ethnomethodological thinking, it also spawned Lucy Suchman's influential work. Suchman challenged the traditional cognitive psychology of goals and plans by highlighting the interactional uses of plans when using and maintaining a photocopier - plans served a normative role in justifying conduct but did not explain, let alone causally constrain, the sorts of ad hoc situated practices involved in running the copier (Suchman, 1987).

Conversation analysts have had an ambivalent response to cognition. Some have expressed considerable caution about taking cognitivist notions such as strategies at face value (Heritage, 1990/1), while others have argued that some kind of cognitive notions are inescapable in conversation analytic work, so it is important to deal with them clearly and explicitly (Pomerantz, 1990/1). This ambivalence is picked up in analytic practice. Some conversation analytic research has reworked cognitivist notions in terms of conversational routines. An example of this is Emanuel Schegloff's (1992) transformation of the notion of intersubjectivity from a phenomenological merging of consciousness into a set of interaction procedures involving the management of repair. Other research has taken cognitivist notions as an unproblematic start point for research. For example, Paul Drew (1995) seems happy to do business with the idea of 'anticipatory interactive planning'.

Why has there been this difference in approach to social structure and cognition? It may be because conversation analysis has its origins and much of its disciplinary base in sociology. Conversation analysts have rethought social structure as they have been forced to deal with sociology's dominant conceptions of society and to counter mainsteam attacks on their legitimacy. In contrast, conversation analysts have found cognitive psychology to be a rather distant discipline, and a discipline, moreover, which has almost entirely ignored it. When cognitive psychologists have wanted to understand language and interaction they have almost invariably looked to the sorts of pragmatic work characteristic of the discourse 
processes tradition (although Clark, 1992, is a rare exception). There is something of the reverse pattern where a respecification model of discourse analysis developed psychology.

\section{Discourse Analysis AND Discursive PSyChOlogy}

Traditionally LSI work in social psychology was cognitivist, and strongly influenced by what, in North America anyway, became the dominant social cognition tradition by the start of the 1990s. In Britain in particular a type of discourse analysis emerged in social psychology under the influence of a mixture of conversation analysis, post-structuralism and rhetoric (Billig, 1987; Potter and Wetherell, 1987). This was very much within the Respecification Model of LSI, fundamentally transforming the social cognitivist assumptions of social psychology.

Consider the example of attitudes. Traditional social psychologists theorized attitudes as underlying mental constructs which influence 'behaviour' and can be used to index how one individual differs from another. Discourse researchers have criticised this notion on both analytic and conceptual grounds, moving the focus on to people's heterogeneous practices of evaluation in particular settings (Potter, 1998). The notion of practice is crucial here - the concern is what is being done with evaluations rather than their role as evidence of putative underlying explanatory entities.

Over the past few years this kind of respecifying critique has been developed beyond the sub discipline of social psychology, and in 1997 Derek Edwards published a major work which drew out the implications of themes in the sociology of scientific knowledge and Harvey Sacks' thinking for the prevailing cognitivist view of psychology (Edwards, 1997; see also, Edwards, 1995). Edwards offers a sweeping reappraisal of the central thesaurus of cognitivist notions, including shared knowledge, scripts, categories, memory, emotion and 
animal and child cognition. Its vision is no less than a full scale discursive psychology. For example, he takes the cognitivist construction of shared knowledge and shows the virtue analytically and theoretically - of respecifying it in terms of practical, situated accomplishments in interaction; that is, of pragmatic intersubjectivity. And he highlights the confused state of traditional research which has made judgements about shared knowledge from a range of more or less technical arenas of interaction without addressing the pragmatics of intersubjectivity.

Reworking cognitive psychology in this way has a range of methodological implications. The most notable is that is provides a principled, theoretically grounded reason for addressing topics that were previously dealt with in exclusively cognitivist terms by focusing on action. Rather than concentrating on putative inner entities and processes that might be occurring within an actor abstracted from action and interaction, the interest is in how cognitive notions are constructed, managed and oriented to in action. Discursive psychologists ask: what does the notion of memory do in some interaction? How is a version of the past constructed to sustain some action? The overwhelming practice of cognitive psychology involves abstracting the person from interaction as far as possible. In discursive psychology, interaction becomes a, perhaps the, fundamental site for studying (a respecified) cognition. Put another way, rather than LSI being a rather marginal subfield of cognitive psychology, cognitive psychology becomes a subfield of LSI.

\section{COGNITION, REALITY AND CONSTRUCTIONISM}

One of the phenomena highlighted in discursive psychological research is the close interrelationship between constructions of cognitive entities of various kinds and constructions of the world (see Edwards, 1997; Edwards \& Potter, 1992; Potter, 1996). 
Versions of 'inner states' can be part of establishing consequential 'facts' about the world. Thus, characterising someone as 'sceptical' may cast their version of the world as cautious but potentially believable; characterising a person as 'jealous' can suggest distortions in his account of his relationship. Conversely, particular descriptions of 'external reality' can be part of established consequential 'facts' about inner states. Describing a woman as 'flirting' can sustain a very different motivational story to 'just messin'.

I am making two points here. First, it is possible - and fruitful - to study the business done by descriptions as they appear in various kinds of interaction. Second, when we consider practices of talk, the boundary between what is cognitive and what is not is particularly permeable. LSI research need not start from the assumption that there must be consequential differences between descriptions of events, social institutions, or cognitive entities. The territorial boundaries of cognition, social structure, action and so on reflect a history of disciplinary colonisation. We have the opportunity to tear up the old maps. At the same time, there has been a flood of work in the last decade that dubs itself 'constructionist'. Often what is being suggested by the construction metaphor is not clear - what precisely is constructed, and how? As I have argued at length (Potter, 1996), constructionism can be given a coherent focus by considering how descriptions are constructed, how they are made factual and what sorts of practices they are involved with. Constructionism, too, could be given an LSI makeover.

\section{LANGUAGE AND Social InTERACTION AfTer the CEnTURY's TuRn}

I have tried to outline a vision of the future of LSI which makes it a central, perhaps foundational, discipline in the social sciences. I have tried to promote the respecification model, and push it to extreme. In particular, I have wanted to show how a discursive 
psychology can build on existing developments to provide a productive alternative to traditional cognitivist cognitive psychology. At the same time, it can provide a coherent focus for the heterogeneous and theoretically fragmented work of constructionism. This vision is an ambitious one, and there is a huge amount of disciplinary inertia in the way of its realization. However, merely having the arguments could generate rich new thinking.

What sort of work would realize this vision? In methodological terms, it would primarily consist in studies of records (audio and video) of 'natural' interaction, where natural means that the interaction was not got up by the researcher in one way or another. That means that it would be overwhelmingly non-experimental (not just because of the well established problems in the critiques of positivism, but because of their patent failure of deal with the reflexive and indexical nature of interaction), and would generally avoid the sorts of interview studies that have been popular in constructionist research (because of their slide into cognitivism, their peculiar interactional status, and their imposition of social science agendas on participants - see Widdicombe and Wooffitt, 1995). It would probably look most similar to the burgeoning CA based work on talk and institutions (Drew and Heritage, 1992), although here the primary focus would not be on how institutions are constituted and oriented to, but on how mind and reality are simultaneously managed in particular settings.

There is already high quality work starting to paint in the detail of this vision. Take two 'psychological' topics: counselling and perception. Annsi Peräkylä (1995) has studied the production of HIV+ counselling as a practice and an institution, while at the same time considering how the participants construct their worlds and their mental life. Derek Edwards (1995) considered the way couples in relationship counselling produce versions of their own, and their partner's, problems in a way that managed issues of blame and therapeutic outcome. These studies are exemplary, and also illustrate the convergence of work in conversation analysis and discursive psychology. If counselling is an obvious focus for LSI work beyond 
cognitivism, the topic of perception is something of a hard case. It is not easy to think of a less obviously discursive topic. Nevertheless, in a series of major studies Charles and Marjorie Goodwin (Goodwin, 1995, 1997; Goodwin \& Goodwin, 1996, 1997) have shown how perception can be treated not as an inner psychological phenomenon, but as a feature of situated practices where airline workers, chemists and oceanographers have to 'see' particular planes, color changes in reactions, or features of the ocean floor. These studies start to show how that perception is produced in interaction.

Research on Language and Social Interaction is a journal that can be at the heart of these developments. My preference would be for its name not to be taken too seriously, though. Part of the task of the respecification model is to trouble both the notion of language as an abstract system, separable from practices, and the notion of social interaction, with its micro-sociology, leave the big stuff to the social theorists, overtones. A vibrant LSI should not be closed to issues of ideology (Billig, 1992) and social critique (Kitzinger and Frith, in press) and new ways of addressing these issues have been developed. Luckily names don't have to be taken too seriously - Dartmouth (in Devon, not Kansas or Nova Scotia!) still names the town successfully even though the mouth of the river is now some way away.

\section{REFERENCES}

Billig, M. (1987). Arguing and thinking: A rhetorical approach to social psychology. Cambridge: Cambridge University Press.

Billig, M. (1992). Talking of the royal family. London: Routledge.

Button, G., Coulter, J., Lee, J. and Sharrock, W. (1995). Computers, Minds and Conduct. Oxford: Polity.

Clark, H.H. (1992). Arenas of language use. Chicago: University of Chicago Press. 
Coulter, J. (1990). Mind in action. Oxford: Polity.

Drew, P. \& Heritage, J.C. (Eds.) (1992). Talk at work: Interaction in institutional settings. Cambridge: University of Cambridge Press.

Drew, P. \& Sorjonen, M-L. (1997) Institutional dialogue. In van Dijk, T.A. (Ed.) Discourse as Interaction (Discourse Studies: A multidisciplinary introduction, volume 2) (pp 92118). London; Sage.

Drew, P. (1995). Interaction sequences and 'anticipatory interactive planning.' In E. Goody (Ed.), The social origins of human intelligence. Cambridge: Cambridge University Press.

Edwards, D. (1995a). Sacks and psychology, Theory and Psychology, 5, 579-596.

Edwards, D. (1995b). Two to tango: Script formulations, dispositions, and rhetorical symmetry in relationship troubles talk, Research on Language and Social Interaction, $28,319-350$.

Edwards, D. (1997). Discourse and cognition. London and Beverly Hills, CA: Sage.

Edwards, D. \& Potter, J. (1992). Discursive psychology. London: Sage.

Goodwin, C. (1995) Seeing in depth, Social Studies of Science, 25, 237-74.

Goodwin, C. (1997) The blackness of black: Color categories as situated practice. In Resnick, L.B., Säljö, R., Pontecorvo, C. \& Burge, B. (Eds). Discourse, Tools, and Reasoning (pp. 111-140). Berlin; Springer.

Goodwin, C. \& Goodwin, M.H. (1996) Seeing as situated activity: Formulating planes. In Engeström, Y. \& Middleton, D. (Eds) Cognition and communication at work (pp. 6195). Cambridge; Cambridge University Press.

Goodwin, C. \& Goodwin, M.H. (1997) Contested vision: The discursive constitution of Rodney King. In Gunnarsson, B-L, Linell, P. \& Nordberg, B. (Eds) The Construction of Professional Discourse (pp. 292-316). London; Longman. 
Heritage, J.C. (1990/1). Intention, meaning and strategy: Observations on constraints in interaction analysis. Research on Language and Social Interaction, 24, 311-332.

Heritage, J.C. (1997) Conversation analysis and institutional talk: Analysing data. In D. Silverman (Ed.) Qualitative research: Theory, method and practice (pp. 161-182) London; Sage.

Kitzinger, C. and Frith, H. (in press) Just say no? Using conversation analysis to understand how young women talk about refusing sex, Discourse and Society.

Peräkylä, A. (1995). AIDS counselling: Institutional interaction and clinical practice. Cambridge: Cambridge University Press.

Pomerantz, A. (1990/1991) Mental concepts in the analysis of social action, Research on Language and Social Interaction, 24, 299-310.

Potter, J. \& Wetherell, M. (1987). Discourse and social psychology: Beyond attitudes and behaviour. London: Sage.

Potter, J. (1996). Representing reality: Discourse, rhetoric and social construction. London; Sage.

Potter, J. (1998) Discursive social psychology: From attitudes to evaluations, European Review of Social Psychology, in press.

Schegloff, E.A. (1992). Repair after next turn: The last structurally provided defence of intersubjectivity in conversation. American Journal of Sociology, 97 (5), 1295-1345.

Suchman, L. (1987). Plans and situated actions: The problem of human-machine interaction. Cambridge: Cambridge University Press.

van Dijk, T.A. (1997) Discourse as interaction in society. In T.A. van Dijk (Ed.) Discourse as Social Interaction (Vol. 2 of Discourse Studies: A multidisciplinary introduction). London; Sage. 
Widdicombe, S. \& Wooffitt, R. (1995). The language of youth subcultures: Social identity in action. Hemel Hempstead, UK: Harvester/Wheatsheaf. 